
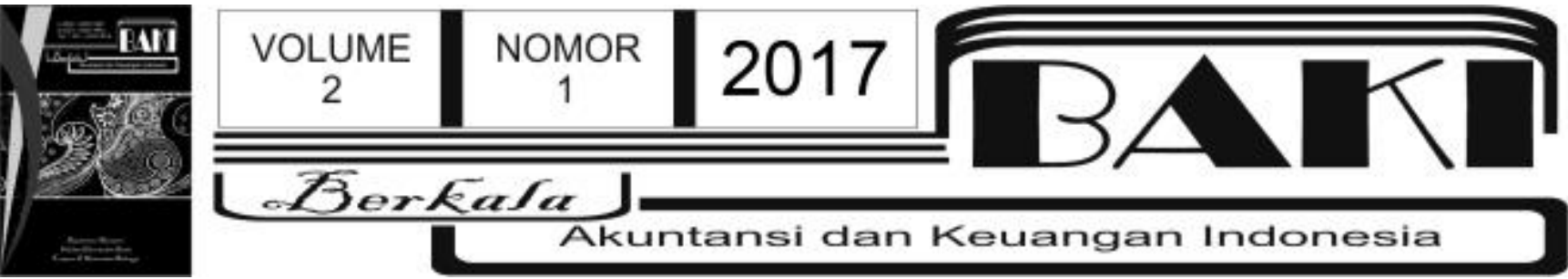

\title{
Faktor-Faktor Manajemen Risiko Terhadap Keputusan Penerimaan Klien Pada Sebuah Kap Non Big 4
}

\author{
Mia Selvina ${ }^{1}$ \\ ${ }^{1}$ Universitas Indonesia \\ 1miaselvina@gmail.com
}

INFO ARTIKEL

\begin{tabular}{l}
\hline Histori Artikel: \\
Tanggal Masuk 17 Februari 2017 \\
Tanggal Diterima 26 Februari \\
2017 \\
Tersedia Online 9 Mei 2017 \\
\hline Kata Kunci: \\
kantor akuntan publik; \\
manajemen risiko; \\
penerimaan klien; \\
risiko perikatan audit
\end{tabular}

\author{
A B STRAK
}

Penelitian ini bertujuan untuk memberikan bukti empiris mengenai evaluasi manajemen risiko pada sebuah kantor akuntan publik non big 4 terhadap keputusan penerimaan klien. Manajemen risiko terbagi menjadi 3 kategori besar yaitu risiko bisnis klien, risiko bisnis audit, risiko bisnis KAP. Sampel yang digunakan pada penelitian ini adalah klien yang mengajukan permohonan jasa audit pada sebuah kantor akuntan publik yang tidak termasuk dalam KAP Big 4. Penelitian ini membuktikan faktorfaktor yang mempengaruhi penerimaan klien pada KAP non big 4 adalah integritas manajemen, risiko bisnis klien, risiko audit, dan audit fee.

\section{Pendahuluan}

Akuntan menjadi salah satu profesi prioritas yang perlu disiapkan dalam rangka menghadapi Masyarakat Ekonomi ASEAN 2015 (Depnakertrans 2015). Pemberlakuan Masyarakat Ekonomi ASEAN 2015 membutuhkan kompetensi dan daya saing tinggi karena auditor Indonesia akan bersaing dengan auditor asing dalam memperoleh pasar kerja dan klien. Auditor dituntut untuk memiliki kompetensi dan profesionalitas untuk menjaga kredibilitas perusahaan. Dengan adanya Masyarakat Ekonomi ASEAN 2015 diprediksi persaingan antar KAP akan semakin ketat.

Di Indonesia, regulasi auditor yang terdapat pada Keputusan Menteri Keuangan no 423 tahun 2002 mengatur kantor akuntan publik paling lama 5 tahun buku berturut-turut dan oleh seorang akuntan publik paling lama untuk 3 tahun buku berturut-turut. Regulasi ini untuk mengurangi kefamiliaran hubungan klien dan auditor yang merusak independensi auditor juga untuk mendapatkan perspektif baru dari auditor yang berbeda (Flirt 2012). 
Saat kantor akuntan publik (KAP) akan menghadapi persaingan yang meningkat akibat MEA 2015, KAP perlu melakukan evaluasi klien sebelum memutuskan penerimaan klien. Evaluasi klien dilakukan untuk mengidentifikasi dan mengukur risiko sehingga dapat meningkatkan metode pertahanan risiko karena keputusan auditor dan konsekuensi kegagalannya sangat kompleks (Houtson et al. 1999). Keputusan penerimaan klien berpengaruh terhadap audit fee dan resiko litigasi auditor maupun KAP (Johnstone 2003). Kasus litigasi dapat merusak profesionalitas auditor maupun KAP bahkan hingga menyebabkan kerugian KAP. Hal ini terjadi karen auditor bertanggung jawab dalam menggaransi laporan keuangan perusahaan bebas dari salah saji yang material (Abdullatif 2013).

Penelitian ini menggunakan manajemen resiko pada penelitian Johnstone (2003), yaitu risiko klien (client risk), risiko audit (audit risk) dan risiko KAP (auditor's business risk). Peneliti di Indonesia belum banyak melakukan kajian mengenai manajemen risiko dalam keputusan penerimaan klien. Mayoritas KAP di Indonesia adalah KAP sedang dan besar (Wondabio 2006) sehingga penelitian ini mengambil sampel dari sebuah KAP non big 4. Ukuran KAP menyebabkan perbedaan karakteristik pada KAP tersebut. Wondabio (2006) melakukan penelitian serupa dengan menggunakan KAP Big 4 sebagai sampel. Hasil yang didapat adalah risiko klien, risiko audit, risiko KAP berpengaruh signifikan dalam proses penerimaan klien di KAP.

KAP non big 4 memiliki klien yang lebih sedikit daripada KAP besar. Besar audit fee pada KAP tersebut juga lebih sedikit dibandingkan KAP besar. Faktor ini akan berpengaruh terhadap keputusan penerimaan klien yang berlaku pada masing-masing KAP. Penelitian ini bertujuan untuk memberikan bukti empiris mengenai faktor-faktor manajemen risiko di kantor akuntan publik non big 4 yang mempengaruhi keputusan penerimaan klien di KAP non big 4, sehingga penelitian ini memberi manfaat bagi perusahaan dan investor dalam memilih KAP yang memeriksa keuangan perusahaan.

\section{Tinjauan Pustaka}

\subsection{Manajemen Risiko pada Kantor Akuntan Publik}

Layaknya perusahaan-perusahaan lain, kantor akuntan publik juga menghadapi beragam risiko. Risiko merupakan hal yang tidak dapat dihilangkan, tetapi dapat dikelola dengan baik. Manajemen risiko penting untuk melindungi aset, keuangan, dan juga operasional kantor akuntanpublik. Kehadiran manajemen risiko juga penting untuk memberikan kepatuhan hukum dan tata kelola perusahaan yang lebih baik. Melalui manajemen risiko pula, kantor akuntan publik dapat memberikan jasa yang lebih baik kepada klien, sekaligus mendapatkan reputasi dan kredibilitas yang baik. Manajemen risiko juga memberikan andil besar bagi peningkatan 
kepercayaan perusahaan. Manajemen risiko sangat penting bagi keberlangsungan hidup perusahaan. Semakin baik pengelolaan, semakin panjang harapan hidup perusahaan (Mustofa 2014).

Risiko pada kantor akuntan publik terdiri dari risiko internal dan risiko eksternal. Risiko internal terdiri dari: bangunan dan lokasi kantor, ancaman terhadap brand image dan reputasi. Risiko eksternal terdiri dari: risiko oleh klien dan risiko kompetitor (Mustofa 2014). Dalam penelitian ini dibahas risiko eksternal yaitu risiko oleh klien. Risiko tidak akan pernah bisa dihilangkan namun dapat diminimalisir sehingga tidak mengganggu hidup perusahaan. Untuk itu peran dari manajemen risiko adalah untuk meminimalisir risiko tersebut.

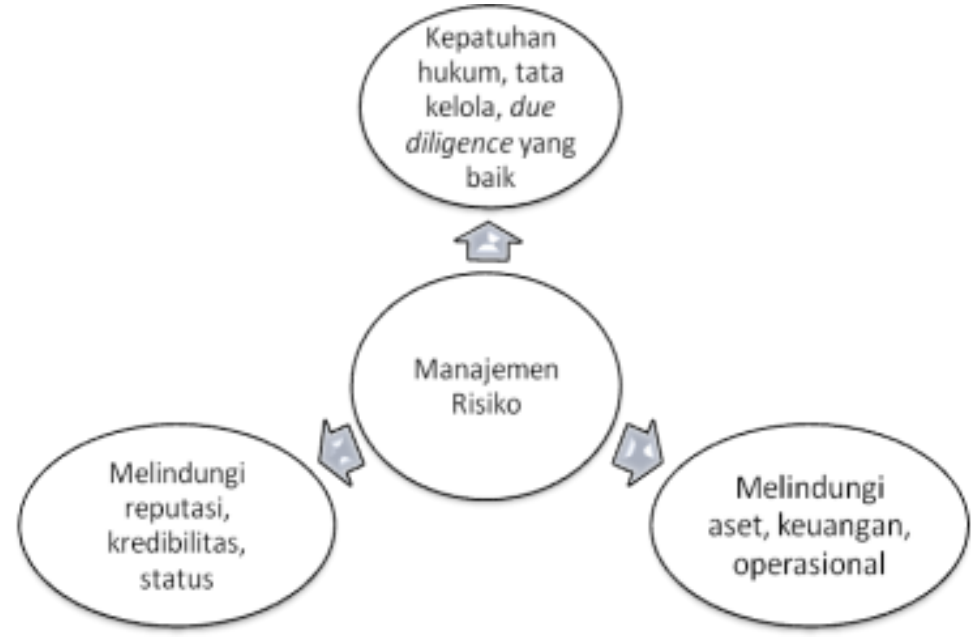

Gambar 1. Dampak Manajemen Risiko pada Perusahaan Sumber: IFAC (2013) dalam Mustofa (2014)

\subsection{Ukuran KAP dan Kualitas Audit}

DeAngelo (1981) mengemukakan pandangan bahwa kualitas audit tidak hanya ditentukan oleh ukuran KAP. Apabila standar profesi dan kualifikasi terjaga, maka tidak adil jika ada diskriminasi antara KAP besar dengan KAP lainnya. Namun temuan DeAngelo (1981) membuktikan bahwa semakin besar ukuran KAP lebih menghasilkan kualitas audit yang tinggi.

KAP besar lebih banyak memiliki klien. Biaya awal audit yang cukup besar membuat auditor tidak bertindak oportunistik, sehingga kualitas audit semakin tinggi. Menurut DeAngelo (1981) kualitas auditor dapat diukur dari:

1. kemungkinan untuk menemukan penyimpangan

2. kemungkinan melaporkan temuan penyimpangan

Auditor yang menemukan penyimpangan dan melaporkan penyimpangan klien, maka ada konsekuensi kemungkinan terminasi kontrak di tahun mendatang. Sebaliknya, jika auditor tidak melaporkan penyimpangan klien dan tindakan ini diketahui di masa mendatang, maka auditor 
akan kehilangan reputasi dan kehilangan klien-klien lainnya yang semula sudah mengikat kontrak dengannya, atau konsekuensi lain menurunnya tingkat fee auditor.

Tabel 2.1 Penelitian Terdahulu KAP Big 4 dan Non Big 4

\begin{tabular}{|c|c|}
\hline $\begin{array}{c}\text { Nama Peneliti dan Judul } \\
\text { Penelitian }\end{array}$ & Keterangan dan Hasil Peneliti \\
\hline $\begin{array}{l}\text { Francis dan Yu (2009) } \\
\text { Big } 4 \text { Office Size and Audit } \\
\text { Quality }\end{array}$ & $\begin{array}{l}\text { Penelitian ini melihat perbedaan kualitas audit KAP big } 4 \text { dan } \\
\text { non big } 4 \text { dari issue going concern laporan audit. Hasil temuan } \\
\text { bahwa KAP big } 4 \text { rata-rata memiliki kualitas audit lebih baik } \\
\text { dibanding KAP non big } 4\end{array}$ \\
\hline $\begin{array}{l}\text { Wibowo dan Rossieta (2009) } \\
\text { Faktor-faktor Determinasi } \\
\text { Kualitas Audit - Suatu Studi } \\
\text { dengan Pendekatan Earning } \\
\text { Surprise Benchmark }\end{array}$ & $\begin{array}{l}\text { Peneltian ini mengukur kualitas audit dari KAP big } 4 \text { dan non } \\
\text { big } 4 \text { dari rerata ROA, bila rerata ROA. } \\
\text { Hasilnya bahwa semakin besar ukuran KAP maka semakin } \\
\text { tinggi kualitas audit yang dihasilkan }\end{array}$ \\
\hline $\begin{array}{l}\text { Diaz (2009) } \\
\text { Analisis Reaksi Pasar terhadap } \\
\text { Pengumuman Pergantian } \\
\text { Kantor Akuntan Publik }\end{array}$ & $\begin{array}{l}\text { Penelitian ini melihat pengaruh reaksi pasar apabila } \\
\text { perusahaan mengganti KAP dari KAP big } 4 \text { ke KAP non big } 4 \\
\text { dan sebaliknya. } \\
\text { Penemuan mengungkapkan bahwa keduanya berpengaruh } \\
\text { negatif baik pergantian dari KAP big } 4 \text { menjadi KAP non big } 4 \\
\text { maupun sebaliknya }\end{array}$ \\
\hline $\begin{array}{l}\text { Jenkins dan Velury (2011) } \\
\text { The emergence of second-tier } \\
\text { auditors in the post-SOX era: An } \\
\text { analysis of } \\
\text { accounting conservatism }\end{array}$ & $\begin{array}{l}\text { Penelitian ini membandingkan antara KAP big } N \text { dan second } \\
\text { tier dilihat dari earning conservatism sebelum dan sesudah } \\
\text { periode SOX. Hasil yang diperoleh dari penelitian ini } \\
\text { mendukung rekomendasi PCAOB bahwa KAP second tier } \\
\text { direkomendasikan menjadi pilihan alternatif karena dapat } \\
\text { meningkatkan laporan konservatif dari klien. }\end{array}$ \\
\hline $\begin{array}{l}\text { Boone et al. (2011) } \\
\text { Do the Big } 4 \text { and the Second- } \\
\text { tier firms provide audits of } \\
\text { similar quality? }\end{array}$ & $\begin{array}{l}\text { Penelitian ini membandingkan kualitas audit dari KAP big } 4 \\
\text { dan second tier dilihat dari laporan audit issue going concern. } \\
\text { Hasil temuan adalah terdapat perbedaan kualitas antara KAP } \\
\text { big } 4 \text { dengan KAP second tier namun perbedaan tersebut } \\
\text { sangat kecil sehingga KAP second tier bisa dijadikan alternatif } \\
\text { dari KAP big } 4 \text {. }\end{array}$ \\
\hline $\begin{array}{l}\text { Chen dan Hsu (2009) } \\
\text { Auditor Size, Auditor Quality, } \\
\text { and Auditor Fee Premiums: } \\
\text { Further Evidence from the } \\
\text { Public Accounting Profession }\end{array}$ & $\begin{array}{l}\text { Penelitian ini melihat hubungan antara ukuran KAP terhadap } \\
\text { kualitas audit dan audit fee. Hasil yang diperoleh bahwa KAP } \\
\text { besar lebih berkualitas daripada KAP lainnya. Audit fee KAP } \\
\text { besar lebih tinggi dari pada KAP lainnya. }\end{array}$ \\
\hline
\end{tabular}

Auditor dengan jumlah klien lebih banyak, tidak mempunyai kecenderungan untuk melakukan kecurangan demi menjaga hubungan dengan klien lainnya. Auditor dengan ukuran lebih besar mempunyai jaminan collateral lebih tinggi sehingga lebih menjaga kualitas audit. DeAngelo (1981) juga menyebutkan 3 kemungkinan penguatan atau pelemahan hubungan ukuran KAP dan kualitas (dengan mengabaikan potensi cost dan benefit dari perusahaan besar):

a. Semakin besar kantor akuntan publik, semakin besar keuntungan komparatif dalam memonitor perilaku individu auditor, sesuai pendapat Watts and Zimmerman (1981). 
b. Sebaliknya, semakin banyak auditor yang tergabung (partner), semakin banyak insentif individu partner yang tersembunyi, sesuai pendapat Alchian dan Demsetz (1972). Asumsi ini bisa melemahkan hubungan antara ukuran dan kualitas auditor.

c. Semakin besar KAP semakin banyak klien yang mengikat kontrak dengannya, semakin rendah sumbangan pendapatan dari total pendapatan kantor akuntan publik, sehingga semakin besar kemungkinan auditor untuk melaporkan temuan penyimpangan.

Tabel 2.2 Penelitian Terdahulu tentang Penerimaan Klien

\begin{tabular}{|c|c|}
\hline Peneliti dan Judul Penelitian & Tujuan, Variabel dan Hasil Penelitian \\
\hline $\begin{array}{l}\text { Johnstone dan Bedard (2003) } \\
\text { Risk Management in Client } \\
\text { Acceptance Decision }\end{array}$ & $\begin{array}{l}\text { Penelitian ini fokus menguji tenaga spesialis dan audit fee } \\
\text { (digambarkan dengan billing rate) sebagai variabel } \\
\text { moderasi. Kedua variabel ini dianggap mampu mengurangi } \\
\text { risiko perikatan klien dan mempengaruhi penerimaan klien. } \\
\text { Variabel dependen yang digunakan yaitu: } \\
\text { 1. Risiko Audit } \\
\text { Fraud Risk berdasarkan SAS No. } 82 \text { [AICPA 1997b] : } \\
\text { karakteristik manajemen, kontrol lingkungan } \\
\text { Eror Risk berdasarkan SAS No. } 47 \text { [AICPA 1993] : } \\
\text { Kompleksitas transaksi, indikasi kemampuan menyajikan } \\
\text { laporan keuangan yang akurat dan tepat waktu. } \\
\text { 2. Risiko Bisnis Klien (RBK) } \\
\text { RBK diukur dengan melihat going concern risk. } \\
\text { 3. Risiko Bisnis KAP (RKAP) } \\
\text { RKAP diukur dengan melihat apakah saham klien } \\
\text { dimiliki oleh publik. } \\
\text { 4. ROA, leverage, client revenue, jenis industri sebagai } \\
\text { variabel kontrol } \\
\text { Hasil yang diperoleh pada penelitian ini adalah tenaga } \\
\text { spesialis terbukti memoderasi pengaruh risiko audit dan } \\
\text { klien yang berisiko going concern untuk diterima sebagai } \\
\text { klien. Audit fee yang tinggi mampu memoderasi klien } \\
\text { dengan risiko going concern dan klien dengan kepemilikan } \\
\text { saham oleh publik untuk diterima sebagai klien. }\end{array}$ \\
\hline $\begin{array}{l}\text { Wondabio (2006) } \\
\text { Evaluasi Manajemen Risiko Kantor } \\
\text { Akuntan Publik dalam Keputusan } \\
\text { Penerimaan Klien Berdasarkan } \\
\text { Pertimbangan dari Risiko Klien, } \\
\text { Risiko Audit, dan Risiko Bisnis KAP }\end{array}$ & $\begin{array}{l}\text { Penelitian ini menguji hal yang sama dengan penelitian } \\
\text { Johnstone dan Bedard (2003) namun menggunakan model } \\
\text { hubungan langsung } \\
\text { Variabel yang digunakan dalam penelitian ini: } \\
\text { 1. Integritas manajemen } \\
\text { 2. Risiko bisnis klien } \\
\text { 3. Risiko audit } \\
\text { 4. Risiko bisnis KAP } \\
\text { 5. Audit fee recovery } \\
\text { 6. Tenaga audit spesialis } \\
\text { 7. ROA dan leverage sebagai variabel kontrol } \\
\text { Hasil penelitian ini integritas manajemen, risiko bisnis, risiko } \\
\text { audit, dan leverage mempengaruhi keputusan penerimaan } \\
\text { klien. }\end{array}$ \\
\hline
\end{tabular}

Dari ketiga penguatan dan pelemahan tersebut, penelitian DeAngelo (1981) membuktikan bahwa ukuran auditor (KAP) menjadi proksi kualitas audit dan menghasilkan justifikasi untuk 
penggantian dan diskriminasi kontrak. Perubahaan auditor memotivasi peningkatan kualitas audit, perubahan ke auditor besar pada saat menjelang IPO dinyatakan konsisten terhadap peningkatan kualitas audit.

Penelitian terbaru dalam 10 tahun terakhir menguji ukuran KAP dan kualitas audit. Beberapa penelitian tersebut antara lain tampak pada Tabel 2.1 di halaman sebelumnya. Dari beberapa penelitian ini dapat disimpulkan bahwa ukuran KAP berpengaruh terhadap kualitas audit. Namun kedua penelitian ini menggunakan sampel KAP big 4 saja. Kedua penelitian tersebut menggunakan KAP big 4 sebagai sampel penelitian, sehingga belum menggambarkan keputusan penerimaan klien pada KAP non big 4.

Data dari Pusat Pembinaan Profesi Keuangan Kementerian Keuangan Republik Indonesia yang dikeluarkan pada tahun 2014 menemukan bahwa jumlah klien KAP di Indonesia sebanyak 30.536 perusahaan, sebagian besar menerima jenis jasa audit umum (24.378 perusahaan atau $79,84 \%$ ). PPPK membagi Ukuran KAP menjadi 5 bagian berdasarkan jumlah rekan.

\section{Gambar 3. Perolehan 10 KAP dengan Jumlah Klien Terbesar dan Proporsi Jumlah Klien berdasarkan Ukuran KAP}

Sumber: Profil Akuntan Publik di Indonesia PPPK hal 33
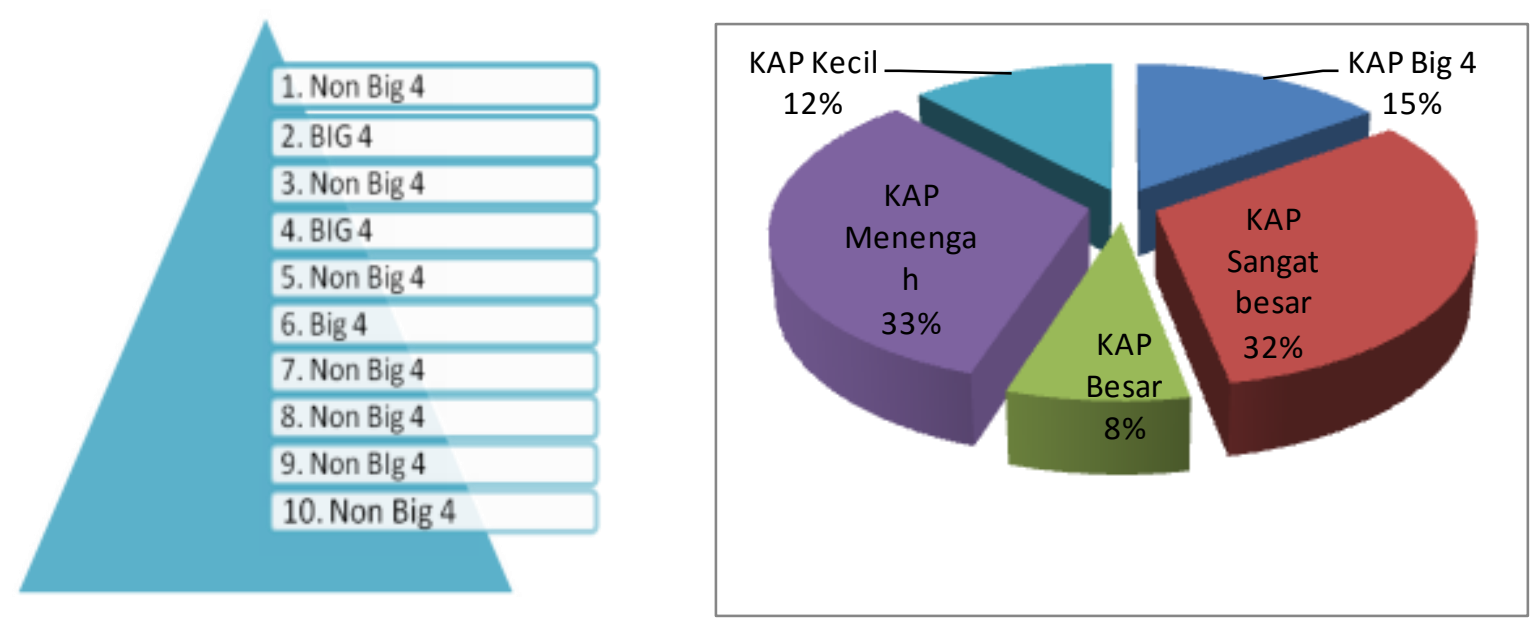

\subsection{Pengembangan Hipotesis}

\subsubsection{Integritas Manajemen terhadap Keputusan KAP untuk Menerima Klien}

Integritas manajemen penting sebagai bahan pertimbangan untuk pengambilan keputusan penerimaan klien. Tanpa adanya integritas manajemen, internal kontrol pada perusahaan tidak akan mengurangi salah saji pada laporan keuangan. Selain itu, manajer adalah pihak yang menyediakan dokumen-dokumen perusahaan selama proses audit sehingga auditor perlu hatihati dalam menilai integritas manajemen yang kredibel dalam menyediakan bukti-bukti atau 
dokumen yang diperlukan selama proses audit (Houston et al. 1999). Cohen (2005) menemukan bukti bahwa intergritas manajemen berpengaruh dalam keputusan penerimaan klien.

Hipotesis 1: Integritas manajemen mempengaruhi keputusan KAP untuk menerima klien

\subsubsection{Risiko Bisnis Klien terhadap Keputusan KAP untuk Menerima Klien}

Auditor perlu mengukur karakteristik klien untuk menilai risiko bisnis klien, melihat kemungkinan litigasi dan menentukan rencana audit dan audit fee (Pratt dan Stice 1994). Jika seorang auditor menerima klien yang beresiko, auditor tersebut perlu melakukan pendekatan audit misalnya dengan meningkatkan audit fee untuk mengakomodasi tingginya risiko (Asare et al. 2005).

Houtson (1999) menemukan bukti bahwa risiko bisnis klien menjadi pertimbangan dalam melakukan perencanaan audit, sedangkan Johnstone dan Bedard (2003) menemukan bahwa KAP akan menerima klien yang tidak dalam kondisi going concern.

Hipotesis 2: Risiko bisnis klien mempengaruhi keputusan KAP untuk menerima klien.

\subsubsection{Risiko Audit terhadap Keputusan KAP untuk Menerima Klien}

Auditor perlu meningkatkan usahanya dalam melakukan proses audit pada perusahaan yang terancam litigasi (Huss et al. 2000). Salah saji material bisa saja tidak terungkap selama proses audit, namun ada kemungkinan terungkap pada saat opini audit sudah dikeluarkan. Risiko audit berhubungan dengan individual klien dan risiko litigasi KAP (Huss et al. 2000). Penilaian risiko audit menjadi pertimbangan auditor dalam menentukan audit fee dan auditor profesional. Pada penelitian di Indonesia, risiko bisnis terbukti mempengaruhi auditor dalam pengambilan keputusan untuk menerima klien (Wondabio 2006).

Hipotesis 3: Risiko audit mempengaruhi keputusan KAP untuk menerima klien.

\subsubsection{Risiko Bisnis KAP terhadap Keputusan KAP untuk Menerima Klien}

Auditor bisa menderita kerugian material dan kerusakan reputasi akibat kecerobohan klien dalam menyajikan laporan keuangan yang tidak terdeteksi oleh auditor atau kegagalan bisnis klien (Houtson et al. 1999). Pihak-pihak tertentu dapat menuntut auditor atas opini yang dikeluarkannya jika dianggap merugikan pihak tersebut. Tuntutan ini menyebabkan kerugian auditor baik dari segi material maupun reputasi auditor dan KAP (Huss et al., 2000). Oleh sebab 
itu risiko bisnis KAP menjadi salah satu faktor penting yang dipertimbangakan pada saat pengambilan keputusan dalam menerima klien.

Pemilihan klien yang selektif akan meningkatkan jasa audit yang lebih handal. Beberapa kasus di Indonesia yang telah disebutkan di awal telah membuktikan bahwa klien dapat menyebabkan kerugian kantor akuntan publik dan auditornya. Berdasarkan penjelasan di atas maka hipotesis yang diambil adalah

Hipotesis 4: Risiko bisnis KAP mempengaruhi keputusan KAP untuk menerima klien

\subsubsection{Audit Fee terhadap Keputusan KAP untuk Menerima Klien}

Klien yang memiliki tingkat risiko audit yang tinggi membutuhkan biaya yang lebih besar untuk proses audit dan hal ini berhubungan juga dengan risiko kegagalan audit sebagai jaminan dalam menghadapi kemungkinan litigasi atau publikasi negatif mengenai KAP (Johnstone 2000). Di tengah keperluan kompensasi insentif dan persaingan bisnis antar KAP, auditor masih mempertimbangkan audit fee dalam menerima klien (Asare 2005).

Hipotesis 5: Audit fee mempengaruhi keputusan KAP untuk menerima klien.

\subsubsection{Tenaga Audit Spesialis terhadap Keputusan KAP untuk Menerima Klien}

Tenaga audit spesialis mengurangi risiko audit dan risiko bisnis KAP (Johnstone dan Bedard 2003). Beberapa penelitian menunjukan bahwa keberadaan tenaga spesialis mempengaruhi keputusan KAP untuk menerima klien karena tenaga spesialis audit ini akan menghasilkan audit yang lebih berkualitas (Johnstone dan Berard 2003). Oleh sebab itu KAP akan lebih mempertimbangan untuk menerima klien apabila ketersediaan audit spesialis sesuai dengan jenis industri klien karena auditor ingin memberikan opini audit yang berkualitas untuk menjaga kompetensi KAP dan mencegah terjadinya risiko-risiko akibat proses audit.

Hipotesis 6: Tenaga Audit Spesialis mempengaruhi keputusan KAP untuk menerima klien 
Gambar 4. Kerangka Penelitian

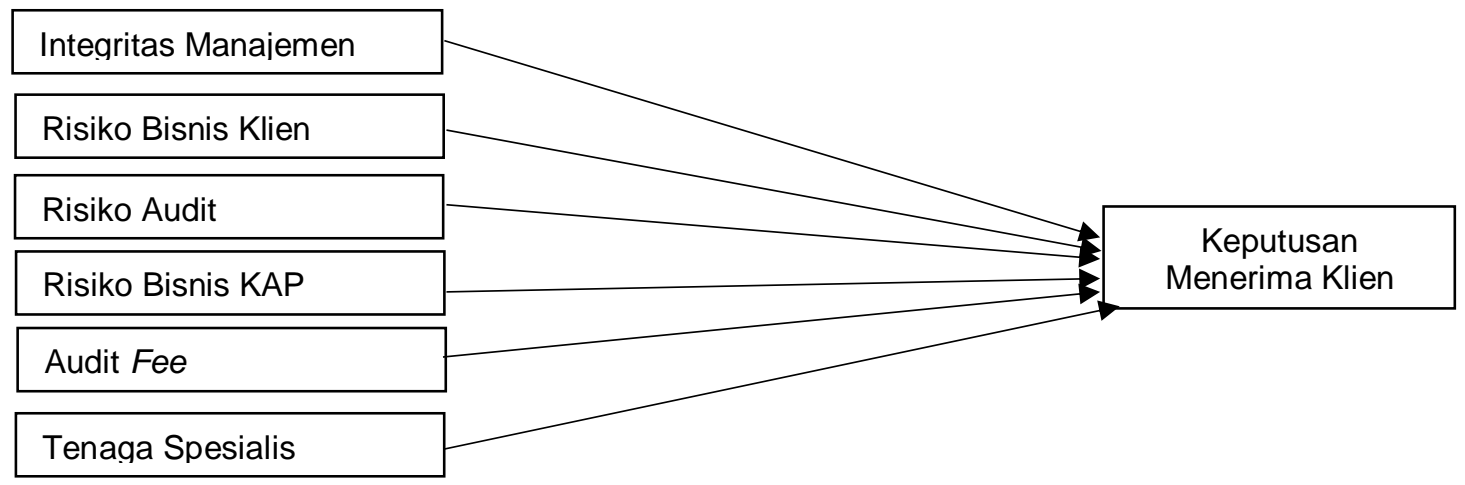

\section{Metodologi Penelitian}

\subsection{Populasi dan Sampel Penelitian}

Populasi dalam penelitian ini adalah perusahaan yang pernah mengajukan permohonan audit pada kantor akuntan publik di Indonesia. Sampel pada penelitian ini adalah perusahaan yang telah mengajukan permohonan audit kepada sebuah KAP dan telah dievaluasi memenuhi kriteria untuk diterima sebagai klien dan yang tidak diterima sebagai klien oleh kantor akuntan publik.

Periode penelitian adalah sepanjang tahun 2014. KAP yang dipilih sebagai tempat pengambilan sampel adalah KAP non big 4 berdasarkan Profil Akuntan Publik di Indonesia yang dikeluarkan oleh PPPK. KAP yang dimaksud adalah KAP yang bukan termasuk dalam KAP big 4 yang terdiri dari EY, PWC, Deloitte, KPMG.

\subsection{Proses Pengambilan Sampel}

Penelitian ini menggunakan data primer. Penelitian ini menyiapkan formulir checklist sebagai alat ukur tingkat risiko klien, risiko audit dan risiko bisnis KAP dan untuk menggali informasi tentang audit fee dan keperluan tenaga spesialis. Pengumpulan data primer dilakukan dengan mendatangi sebuah KAP dan mengevaluasi data penerimaan klien pada KAP tersebut. Jika data yang dibutuhkan untuk penelitian ini tidak lengkap atau tidak tersedia di KAP, maka dilakukan wawancara kepada pihak admistrasi KAP maupun auditor yang kompeten menjawab informasi tersebut.

Data perusahaan yang menjadi sampel pada penelitian ini merupakan data rahasia KAP, sehingga peneliti tidak mendapatkan detail informasi mengenai jenis perusahaan dan ukuran perusahaan. Oleh karena itu, dilakukan wawancara lebih lanjut mengenai gambaran umum data. Dari wawancara tersebut diperoleh hasil deskripsi data sebagai berikut: 


\section{Gambar 5. Deskripsi Data Penerimaan Klien}

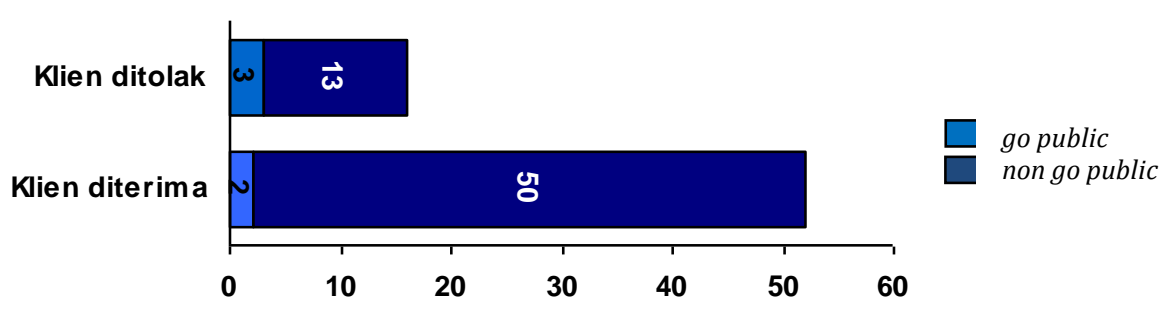

\subsection{Model Penelitian}

Penelitian ini mereplikasi model penelitian Johnstone dan Bedard (2003) mengenai Risk Management and Client Acceptance Decision. Model penelitian Johnstone dan Bedard (2003) ini telah dimodifikasi pada penelitian Wondabio (2006). Atas dasar ketersediaan data pada penelitian ini maka penelitian ini juga menggunakan model penelitian yang digunakan Wondabio (2006) sebagai berikut:

$C A_{i t}=\beta 0+\beta 1 I_{i t}+\beta 2 R B K_{i t}+\beta 3 R A_{i t}+\beta 4 R K A P_{i t}+\beta 5 A R_{i t}+\beta 6 T S_{i t}+\beta 7 R O A_{i t}+\beta 8 L E V_{i t}+\mu_{i t}$

Variabel Dependen

$\mathrm{CA}_{\text {it }} \quad$ : Client Acceptance

Variabel Dependen

IM $\quad$ : Integritas Manajemen

RBK $_{\text {it }} \quad$ : Risiko Bisnis Klien

$\mathrm{RA}_{\text {it }} \quad$ : Risiko Audit

RKAP it $_{\text {it }}$ : Risiko Bisnis KAP

$\mathrm{AR}_{\mathrm{it}} \quad$ : Audit Recovery

TS : : Tenaga Auditor Spesialis

Variabel Kontrol

$\begin{array}{ll}\text { ROA }_{\text {it }} & : \text { Return on Asset } \\ \text { LEV }_{\text {it }} & : \text { Leverage }\end{array}$




\subsection{Pengukuran Variabel}

\subsubsection{Ukuran KAP}

KAP yang digunakan untuk penelitian ini adalah KAP non big 4. Adapun yang termasuk KAP non big 4 adalah KAP yang tidak berafiliasi dengan KAP Big 4 (PWC, Delloite, EY dan KPMG).

\subsubsection{Manajemen Risiko}

Manajemen risiko pada penelitian ini terdiri dari beberapa variabel. Manajemen Risiko sebagai variabel independen dalam penelitian ini adalah sebagai berikut. Faktor-faktor yang digunakan sebagai pengukuran dan cara scoring masing-masing variabel pada penelitian ini dapat dilihat pada lampiran 1.

1. Risiko Klien

Risiko klien dibagi menjadi 2 variabel yaitu:

a. Integritas Manajemen

Pengukuran integritas manajemen pada penelitian ini menggunakan skoring berisi faktorfaktor yang menggambarkan integritas manajemen yaitu karakteristik dan integritas manajemen dan struktur organisasi manajemen. Faktor-faktor ini berdasarkan penelitian Wondabio (2006) merujuk kepada Colbert (1996).

b. Risiko Bisnis Klien

Risiko klien pada penelitian Johnstone dan Bedard (2003) menggunakan pengukuran risiko klien dengan melihat kondisi going concern klien. Risiko bisnis pada penelitian ini diukur dengan scoring dari hasil checklist form yang berisi faktor risiko bisnis klien yaitu jenis bisnis dan kondisi keuangan klien. Faktor-faktor ini berdasarkan penelitian Wondabio (2006) merujuk kepada Colbert (1996).

2. Risiko Audit

Risiko audit yang digunakan pada penelitian ini diukur dengan melakukan scoring dari hasil checklist form berisi poin faktor-faktor seperti jenis perjanjian audit, hubungan bisnis dan pihak berelasi, pengetahuan dan pengalaman sebelumnya dan kemungkinan eror dan fraud. Faktorfaktor ini berdasarkan penelitian Wondabio (2006) merujuk kepada Colbert (1996).

3. Risiko Bisnis Auditor/ KAP

Pada penelitian Johnstone dan Bedard (2003), risiko bisnis KAP dilihat dari kepemilikan saham oleh publik. Penelitian ini memodifikasi kondisi tersebut, karena risiko bisnis auditor di Indonesia dan penelitian sebelumnya menunjukan bahwa hasil audit digunakan untuk IPO dan hasil audit untuk keperluan sidang juga meningkatkan risiko bisnis auditor.

4. Audit fee 
Audit fee merupakan besarnya pembayaran jasa audit yang diberikan klien kepada auditor. Berdasarkan penemuan saat proses pengumpulan data, informasi audit fee tidak dapat diberikan oleh KAP karena sifatnya rahasia. Oleh sebab itu, pengukuran audit fee diganti dengan presentase audit recovery. Data audit recoverydidapat dengan menggunakan asistensi dari staf administrasi KAP dengan rumus sebagai berikut:

Audit recovery $=$ audit fee - (biaya audit langsung + biaya tenaga kerja) audit fee

5. Tenaga auditor spesialis

Keputusan KAP untuk menerima klien dipengaruhi oleh ketersediaan auditor yang memiliki kemampuan dalam menguasai industri dan aktifitas operasi yang dijalankan klien. Pada penelitian ini tenaga auditor spesialis diukur dengan menggunakan dummy 1 jika KAP menggunakan tenaga spesialis untuk mengaudit klien, dan 0 jika tidak.

6. Variabel Kontrol

Penelitian ini menggunakan dua variabel kontrol yaitu:

a. Return on Asset (ROA)

ROA digunakan untuk mengkontrol kondisi keuangan klien (Johnstone dan Bedard 2003). Return on asset adalah pengukuran keberhasilan perusahaan dalam menggunakan aset untuk menghasilkan laba independen dari pembiayaan aset (Selling dan Stickney 1989). Return on asset merupakan indikator untuk melihat prospek bisnis perusahaan sedangkan leverage merupakan indikator going concern perusahaan (Wondabio 2006). Penelitian Bell et al. (2001) menggunakan variabel aset dan leverage untuk melihat risiko bisnis klien. Oleh karena itu, penelitian ini menggunakan ROA sebagai variabel kontrol. ROA berasal dari laba sebelum pajak dibagi total aset.

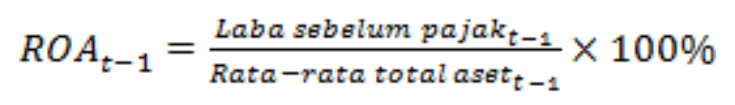

\section{b. Leverage}

Utang yang dimiliki klien juga digunakan untuk mengkontrol kondisi keuangan klien. Perusahaan yang cenderung melakukan pelanggaran kemungkinan memiliki utang yang tinggi (DeFond 2002). Likuiditas merupakan salah satu cara untuk mengukur financial distress (Li 2009).

$$
L E V_{t-1}=\frac{\text { Utang }_{t-1}}{\text { Rata-ratatotalaset } t-1} \times 100 \%
$$




\subsubsection{Keputusan Penerimaan Klien}

Keputusan penerimaan klien dinilai dengan variabel dummy, 1 untuk perusahaan yang permohonan jasa auditnya diterima untuk berlanjut ke proses penandatangan surat perikatan audit dan 0 untukcalon klien yang permohonan jasa auditnya ditolak oleh KAP.

\section{Analisis dan Pembahasan}

\subsection{Analisis Data}

Proses pengumpulan data menghasilkan total sampel sebanyak 52 klien terdiri dari 32 data klien diterima dan 16 data klien yang ditolak.

Tabel 4.1 Deskripsi Analisis Klien

\begin{tabular}{|c|c|c|c|c|}
\hline Variabel & Keterangan & $\begin{array}{c}\text { Total } \\
\text { Sampel } \\
(n=68)\end{array}$ & $\begin{array}{c}\text { Klien } \\
\text { diterima } \\
(\mathrm{n}=52)\end{array}$ & $\begin{array}{c}\text { Klien } \\
\text { ditolak } \\
(n=16)\end{array}$ \\
\hline IM & $\begin{array}{l}\mathrm{IM}=1 \text {, jika klien diindikasi memiliki } \\
\text { intergritas manajemen baik }\end{array}$ & $\begin{array}{c}59 \\
(86,76 \%)\end{array}$ & $\begin{array}{c}51 \\
(98,07 \%)\end{array}$ & $\begin{array}{c}8 \\
(50 \%)\end{array}$ \\
\hline RBK & $\begin{array}{l}\text { RBK = } 1 \text { jika klien diindikasi tidak } \\
\text { memiliki risiko bisnis }\end{array}$ & $\begin{array}{c}51 \\
(75 \%)\end{array}$ & $\begin{array}{c}43 \\
(82,69 \%)\end{array}$ & $\begin{array}{c}8 \\
(50 \%)\end{array}$ \\
\hline RA & $\begin{array}{l}\text { RA = } 1 \text { jika klien diindikasi tidak } \\
\text { membawa risiko audit }\end{array}$ & $\begin{array}{c}61 \\
(89,70 \%)\end{array}$ & $\begin{array}{c}50 \\
(96,15 \%)\end{array}$ & $\begin{array}{c}11 \\
(68,75 \%)\end{array}$ \\
\hline RKAP & $\begin{array}{l}\text { RKAP = } 1 \text { jika klien diindikasi tidak } \\
\text { berisiko terhadap bisnis KAP }\end{array}$ & $\begin{array}{c}65 \\
(95,5 \%)\end{array}$ & $\begin{array}{c}49 \\
(94,23 \%)\end{array}$ & $\begin{array}{c}16 \\
(100 \%)\end{array}$ \\
\hline TS & $\begin{array}{l}\text { TS = } 1 \text { jika memakai tenaga audit } \\
\text { spesialis, }\end{array}$ & $\begin{array}{c}18 \\
(24,4 \%)\end{array}$ & $\begin{array}{c}14 \\
(26,92 \%)\end{array}$ & $\begin{array}{c}4 \\
(25 \%)\end{array}$ \\
\hline
\end{tabular}

\begin{tabular}{|l|l|c|c|c|c|}
\hline \multirow{2}{*}{ Variabel } & \multicolumn{1}{|c|}{ Keterangan } & \multicolumn{2}{c|}{ Full Sampel } & Diterima & Ditolak \\
\cline { 3 - 6 } & & $\begin{array}{c}\text { Mean } \\
\text { (Median) }\end{array}$ & $\begin{array}{c}\text { Minimum- } \\
\text { maximum }\end{array}$ & $\begin{array}{c}\text { Mean } \\
\text { (Median) }\end{array}$ & $\begin{array}{c}\text { Mean } \\
\text { (Median) }\end{array}$ \\
\hline AR & Presentase Laba audit & 0.086 & $-2522-$ & 0.15 & -0.14 \\
& $1-$ (total audit fee / biaya audit) & $(0.12)$ & 1.00 & $(0.14)$ & $(0)$ \\
\hline ROA & Laba bersih sebelum pajak $\div$ & -0.0094 & $-1.92-0.8$ & -0.016 & 0.015 \\
& total aset & $(0.02)$ & & $(0.055)$ & $(0)$ \\
\hline LEV & Total Liabilities $\div$ Total Aset & 0.52 & $0-2.92$ & 2.47 & 0.578 \\
& & $(0.42)$ & & $(0.50)$ & $(0.66)$ \\
\hline
\end{tabular}

Hasil analisis data memperoleh model untuk sebagai berikut:

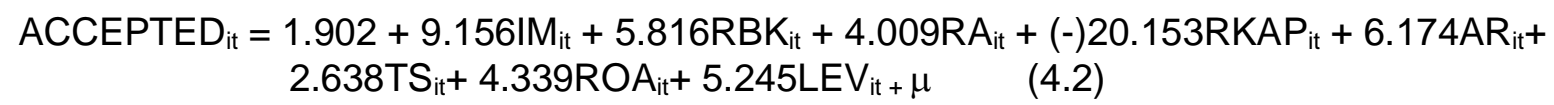

Pengujian ini untuk melihat perbedaan faktor-faktor yang mempengaruhi keputusan penerimaan klien. 
Tabel 4.2. Hasil Uji Wald

\begin{tabular}{|c|c|c|c|c|c|c|c|}
\hline \multirow{10}{*}{ Step $1^{\mathrm{a}}$} & & B & S.E. & Wald & $\mathrm{df}$ & Sig. & $\operatorname{Exp}(B)$ \\
\hline & Im & 9.156 & 3.622 & 6.388 & 1 & $.011^{* *}$ & $\begin{array}{r}9467.3 \\
95\end{array}$ \\
\hline & Rbk & 5.816 & 2.275 & 6.537 & 1 & $.011^{* *}$ & $\begin{array}{r}335.78 \\
8\end{array}$ \\
\hline & $\mathrm{Ra}$ & 4.009 & 2.040 & 3.862 & 1 & $.049^{\star \star}$ & 55.116 \\
\hline & Rkap & -20.153 & 20327.345 & .000 & 1 & .999 & .000 \\
\hline & Ts & 2.638 & 1.911 & 1.905 & 1 & .167 & 13.978 \\
\hline & $\mathrm{Ar}$ & 6.174 & 3.232 & 3.650 & 1 & $\begin{array}{r}.056^{* *} \\
\text { * }\end{array}$ & $\begin{array}{r}480.09 \\
0\end{array}$ \\
\hline & Roa & 4.339 & 2.539 & 2.920 & 1 & $.087^{* *}$ * & 76.616 \\
\hline & Lev & 5.245 & 2.626 & 3.989 & 1 & $.046^{\star \star}$ & $\begin{array}{r}189.54 \\
5\end{array}$ \\
\hline & Constant & 1.902 & 20327.346 & .000 & 1 & 1.000 & 6.701 \\
\hline
\end{tabular}

Data di tabel 4.2 menggambarkan manajemen risiko terhadap keputusan penerimaan klien. Tabel tersebut menunjukan bahwa integritas manajemen, risiko bisnis klien, risiko audit, dan leverage signifikan pada tingkat 5\%. Audit fee dan ROA signifikan pada tingkat $10 \%$.

\section{Uji $\mathrm{G}^{2}$ (likelihood ratio test)}

Pengujian ini untuk melihat uji koefisien regresi secara keseluruhan. Dari olah data SPSS didapat hasil sebagai berikut:

Tabel 4.2. Hasil Uji $G$

\begin{tabular}{|l|r|r|r|}
\hline Step & -2 Log likelihood & $\begin{array}{c}\text { Cox \& Snell } R \\
\text { Square }\end{array}$ & Nagelkerke R Square \\
\hline 1 & $29.650^{\mathrm{a}}$ & .481 & .724 \\
\hline
\end{tabular}

Berdasarkan tabel 4.3 terbukti bahwa -2 Log Likelihood sebesar 29.650. Nagelkerke $R$ square sebesar 0.724 menunjukan bahwa variabel independen dapat menjelaskan variablitas variabel dependen sebesar $72,4 \%$

Interpretasi Slope dan Konstanta

Dari hasil uji wald, nilai Exp $(\beta)$ untuk melihat peluang penerimaan Berdasarkan data tersebut, peluang dapat diintepretasikan sebagai berikut:

1. Peluang perusahaan yang mempunyai integritas manajemen baik untuk diterima sebagai klien sebesar 9436 kali dibandingkan perusahaan yang mempunyai integritas manajemen buruk.

2. Peluang perusahaan yang tidak mempunyai risiko bisnis untuk diterima sebagai klien sebesar 336 kali dibandingkan perusahaan yang berisiko bisnis klien. Peluang perusahaan 
yang tidak mempunyai risiko audit untuk diterima sebagai klien sebesar 55 kali dibandingkan perusahaan yang berisiko audit.

3. Peluang perusahaan yang tidak mempunyai risiko bisnis KAP untuk diterima sebagai klien sebesar 0 kali dibandingkan perusahaan yang berisiko bisnis KAP. Risiko Bisnis KAP tidak berpengaruh terhadap penerimaan klien.

4. Penambahan tenaga spesialis audit tidak berpengaruh langsung terhadap keputusan penerimaan klien.

5. Peluang perusahaan yang menawarkan audit fee sesuai dengan biaya selama proses audit dan terdapat laba di dalamnya untuk diterima sebagai klien sebesar 480 kali dibandingkan perusahaan yang menawarkan audit fee tidak sesuai dengan biaya yang dikeluarkan untuk proses audit.

6. Peluang perusahaan yang memiliki ROA baik untuk diterima sebagai klien sebesar 76 kali dibandingkan perusahaan yang memiliki ROA buruk.

7. Peluang perusahaan yangmemiliki tingkat leverage baik untuk diterima sebagai klien sebesar 189 kali dibandingkan perusahaan yang memiliki tingkat leverage buruk.

8. Jika semua kondisi variabel independen dari model bernilai nol, maka peluang KAP untuk menerima klien dengan kondisi tersebut sebesar 6,7\%.

\subsection{Pembahasan Hipotesis}

Hipotesis 1: Integritas manajemen mempengaruhi keputusan KAP untuk menerima klien.

Hasil statistik menunjukan KAP non big 4 mempertimbangkan integritas manajemen dalam mengambil keputusan untuk menerima klien. Integritas manajemen merupakan faktor yang sangat penting dalam mempengaruhi pekerjaan dan reputasi KAP. Data yang diperoleh menunjukan bahwa 98,07\% klien yang diterima memiliki integritas manajemen yang baik dan $50 \%$ klien ditolak tidak memiliki integritas yang baik.

Hasil wawancara saat pengambilan data menyebutkan bahwa auditor banyak menolak klien yang integritas manajemennya buruk karena berisiko litigasi. Sebagaimana telah disebutkan dalam penjelasan bab sebelumnya bahwa integritas manajemen merupakan pondasi dari internal kontrol yang dapat mempengaruhi pekerjaan dan reputasi akuntan publik (Mustofa, 2014). Oleh sebab itu KAP akan lebih banyak menolak klien yang tidak berintegritas baik karena berisiko kerugian oleh KAP maupun auditor. Berdasarkan penjelasan di atas, hipotesis 1 diterima.

Hipotesis 2: Risiko bisnis klien mempengaruhi keputusan KAP untuk menerima klien.

KAP mempertimbangkan risiko bisnis klien dalam membuat keputusan penerimaan klien. Dari data yang diperoleh menunjukan bahwa $82,69 \%$ klien yang diterima pada KAP yang 
dijadikan sampel tidak memiliki risiko bisnis dan 50\% klien yang ditolak memiliki risiko bisnis. Jenis bisnis, lingkungan bisnis dan stabilitas hasil keuangan yang baik mengurangi kemungkinan rugi akibat menerima klien. Hasil penelitian ini sejalan dengan hasil wawancara dengan auditor yang menyatakan bahwa auditor mempertimbangkan risiko bisnis klien dalam pengambilan keputusan.

Risiko bisnis klien yang paling dipertimbangkan adalah kondisi keuangan klien dan kemungkinan prospek keuangan klien di masa mendatang. Kondisi ini keuangan yang tidak baik mempengaruhi kemampuan klien dalam membayar audit fee (Khrisnan dan Khrisnan, 1997). Berdasarkan penjelasan di atas maka hipotesis 2 diterima.

Hipotesis 3: Risiko audit mempengaruhi keputusan KAP untuk menerima klien.

Risiko audit mempengaruhi keputusan KAP untuk menerima klien. Hal ini ditujukan dengan hasil analisis deskriptif data yaitu 96,15\% klien yang diterima tidak terindikasi membawa risiko audit, sedangkan $68,75 \%$ klien yang ditolak teridentifikasi dapat membawa risiko audit. Hubungan klien dengan pihak berelasi lain, pengalaman auditor dan risiko fraud dan eror dapat membahayakan auditor terkena kasus litigasi. Oleh karena itu risiko audit menjadi faktor yang dipertimbangkan dalam menerima klien.

Hasil wawancara dengan auditor saat proses pengambilan data menyatakan bahwa risiko audit dapat merugikan auditor yaitu jika terkena litigasi. Menurut hasil wawancara dengan pihak KAP pada penelitian ini, KAP non big 4 ini memiliki klien dengan tingkat kompleksitas usaha relatif rendah sehingga tidak banyak yang memiliki risiko audit. Berdasarkan penjelasan di atas, H3 diterima

Hipotesis 4: Risiko bisnis KAP mempengaruhi keputusan KAP untuk menerima klien

Risiko Bisnis KAP tidak berpengaruh terhadap penerimaan klien di KAP. Kondisi klien go public dan non go public, laporan keuangan untuk IPO dan non IPO tidak berpengaruh terhadap keputusan dalam menerima atau menolak klien. Hasil ini didukung oleh data sampel bahwa klien pada KAP non big 4 yang dijadikan sampel hampir tidak ada yang berisiko audit karena tidak go public maupun IPO. Klien yang go public hanya sebanyak 4,5\% dari total klien. $96,15 \%$ klien yang diterima tidak terindikasi membawa risiko bisnis. Begitu pula pada klien yang ditolak, sebanyak 96,15\% tidak terindikasi risiko bisnis KAP. Kondisi ini senada dengan penelitian sebelumnya yang menyatakan bahwa perusahaan go public banyak menggunakan KAP big 4 karena KAP big 4 dianggap lebih berkualitas dan meningkatkan tingkat kepercayaan investor. Berdasarkan penjelasan di atas, maka Hipotesis 4 ditolak karena klien pada KAP non big 4 yang djadikan sampel tidak banyak yang memiliki risiko audit.

Hipotesis 5: Audit fee mempengaruhi keputusan KAP untuk menerima klien. 
Audit fee berpengaruh terhadap keputusan KAP terhadap penerimaan klien. Dari hasil pengumpulan data diperoleh kondisi bahwa adanya praktek low balling. Hal ini diperkuat dengan pernyataan auditor bahwa auditor tetap menerima klien dengan audit fee rendah dengan alasan prospek keuntungan di masa mendatang.

Dari proses pengumpulan data diperoleh data nilai rata-rata audit fee recovery untuk klien yang diterima adalah $15 \%$ dan untuk klien yang ditolak sebesar $-14 \%$. Penelitian ini membuktikan pernyataan Asare et al. (2005) bahwa audit fee masih menjadi faktor yang dipertimbangkan oleh auditor dalam menerima klien walaupun keperluan kompensasi insentif dan persaingan bisnis antar KAP juga dihadapi auditor. Berdasarkan hasil di atas, hipotesis 5 diterima.

\section{Hipotesis 6: Tenaga Audit Spesialis mempengaruhi keputusan KAP untuk menerima klien}

Menurut penelitian Johnstone dan Bedard (2003), tenaga spesialis berperan dalam mengurangi risiko-risiko perikatan dengan klien. Hasil penelitian tersebut berbeda dengan temuan pada penelitian ini. Terdapat $26,92 \%$ klien yang diterima menggunakan tenaga spesialis dan $25 \%$ klien yang ditolak memerlukan tenaga spesialis. Hasil statistik menunjukan bahwa tenaga spesialis tidak signifikan dalam mempengaruhi keputusan penerimaan klien.

Secara teori KAP akan lebih mempertimbangan untuk menerima klien apabila ketersediaan audit spesialis sesuai dengan jenis industri klien karena auditor ingin memberikan opini audit yang berkualitas namun dugaan hasil yang tidak signifikan ini bisa terjadi jumlah data yang minim dan identifikasi tenaga spesialis belum digambarkan secara jelas pada saat proses pengumpulan data sehingga penelitian ini belum mampu menggambarkan keberadaan tenaga spesalis dalam mempengaruhi penerimaan klien. Dari hasil analisa, hipotesis 6 ditolak.

\section{Pengaruh Variabel Kontrol}

Penelitian ini menggunakan ROA dan leverage sebagai variabel kontrol. ROA sebagai indikator untuk melihat prospek bisnis dan leverage merupakan indikator going concern. ROA dan terbukti signifikan dalam keputusan penerimaan klien.

Jika dilihat dari tabel deskripsi analisis klien KAP, nilai maksimum leverage mencapai 2.92. Nilai maksimum tersebut berada pada entitas yang diterima sebagai klien. Setelah melakukan wawancara dengan pihak KAP, leverage menjadi faktor yang dipertimbangkan dalam keputusan penerimaan klien, namun ada beberapa faktor yang menyebabkan klien dengan tingkat leverage tinggi untuk bisa diterima sebagai klien yaitu karena audit fee yang besar dan permintaan pihak bank kepada KAP untuk mengaudit klien tersebut.

ROA dikatakan baik jika bernilai di atas 10\% (Wondabio 2006). Nilai ROA rata-rata untuk klien yang diterima pada penelitian ini yakni $2.47 \%$. ROA berkaitan dengan kondisi keuangan 
klien. Jika kondisi keuangan klien baik maka, risiko kerugian KAP kan semakin kecil Bell et al. (2001).

\section{Kesimpulan, Keterbatasan, dan Saran}

\subsection{Kesimpulan}

Penelitian ini memberikan bukti empiris tentang faktor-faktor yang mempengaruhi keputusan penerimaan klien pada KAP non big 4 . Kantor akuntan publik non big 4 dipilih sebagai sampel karena penelitian-penelitian terdahulu menggunakan sampel KAP big 4 sedangkan kebanyakan KAP di Indonesia adalah KAP non big 4 (Wondabio 2006).

Manajemen risiko pada penelitian ini dilihat dari integritas manajemen, risiko bisnis klien, risiko audit, risiko bisnis KAP, audit fee dan tenaga spesialis. Penelitian ini memberikan sumbangsih terhadap pengembangan teori auditing bahwa KAP non big 4 menerapkan manajemen risiko terhadap keputusan penerimaan klien. Faktor-faktor yang mempengaruhi penerimaan klien pada KAP non big 4 yaitu integritas manajemen, risiko bisnis klien, risiko audit, audit fee, ROA dan leverage. Selain itu penelitian ini menemukan bahwa risiko bisnis KAP tidak berpengaruh pada KAP non big 4 karena klien KAP non big 4 sebagai sampel pada penelitian ini sangat sedikit yang memiliki saham publik. Tenaga spesialis juga tidak berpengaruh langsung terhadap keputusan penerimaan klien.

Pada praktik auditing, KAP non big 4 menerapkan manajemen risiko untuk mengambil keputusan untuk menerima atau menolak klien. walaupun terdapat persaingan bisnis antar KAP non big 4 di Indonesia. Hal ini menunjukan bahwa KAP non big 4 juga mempertimbangkan kualitas audit. Kesalahan dalam menerima klien dapat berisiko terhadap keberlanjutan bisnis KAP (IAPI 2008). Selain itu, KAP non big 4 menerapkan kode etik akuntan dalam hal menjaga kerahasiaan klien. Temuan ini terbukti saat proses pengumpulan data pada penelitian ini. Datadata klien dijaga dengan ketat sehingga pihak luar tidak diijinkan untuk mengakses data maupun mendapatkan data secara lengkap. Berdasarkan hasil temuan - temuan tersebut, KAP non big 4 layak dijadikan alternatif untuk mengaudit perusahaan.

\subsection{Keterbatasan}

Penelitian ini memiliki keterbatasan dalam prosesnya. Keterbatasan utama adalah perihal akses data. Terdapat kesulitan mengakses data yang akan dijadikan sampel karena data mengenai klien pada kantor akuntan publik bersifat sangat rahasia. KAP memegang kode etik akuntan untuk menjaga kerahasiaan klien. Oleh karena itu memerlukan pendekatan ekstra untuk mendapatkan data untuk penelitian ini. Akibat kerahasiaan data dan keterbatasan akses 
ini, melakukan wawancara dengan pihak berkompeten di kantor akuntan publik untuk mendapatkan informasi lebih banyak.

Penelitian ini hanya menggunakan 1 KAP non big 4 sehingga belum mampu menggambarkan kondisi keseluruhan KAP non big 4 yang ada di Indonesia padahal KAP non big 4 di Indonesia jumlahnya sangat mendominasi.

Identifikasi tenaga spesialis pada penelitian ini belum detail karena formulir pengumpulan data hanya mengidentifikasi dengan menanyakan penggunaan tenaga spesialis dengan pilihan ya dan tidak.

\subsection{Saran}

Penelitian selanjutnya sebaiknya meningkatkan jumlah sampel yang didapat dari beberapa KAP non big 4 sehingga cukup menggambarkan kondisi KAP non big 4 di Indonesia. Namun untuk memenuhi hal tersebut cukup sulit karena data yang digunakan untuk penelitian ini bersifat rahasia. Penelitian selanjutnya sebaiknya menggunakan metode lain untuk mengisi keterbatasan dalam hal ini, misalnya dengan metode eksperimen kepada auditor-auditor di kantor akuntan publik.

Identifikasi tenaga spesialis pada penelitian ini masih kurang akibat minimya data. Penelitian selanjutnya sebaiknya memperluas sampel penelitian sehingga data tenaga spesialis lebih banyak teridentifikasi. Adapun jenis-jenis tenaga audit spesialis yang biasa digunakan untuk proses audit adalah: actuary (asuransi), geologist (tambang), pengacara (hukum), appraisal (properti), computer audit (dokumen komputer/ computer audit system).

Saran untuk pemilik entitas dan manajemen, KAP non big 4 menerapkan manajemen risiko terhadap keputusan penerimaan klien. Artinya, KAP non big 4 juga mempedulikan risiko-risiko akibat berikatan dengan klien sehingga KAP non big 4 bisa dijadikan alternatif bagi perusahaan yang biasanya menggunakan KAP big 4, karena masih mempertahankan kualitas audit. Namun berdasarkan penelitian di lapangan bahwa masing-masing KAP berdasarkan ukurannya sudah memiliki pemetaan klien sendiri, perusahaan besar dan ternama biasanya ingin diaudit oleh KAP Big 4. KAP non big 4 pada penelitian ini diduga melakukan praktek low balling. Sehingga faktor ini bisa menjadi bahan pertimbangan bagi entitas dan manajemen dalam melakukan perjanjian audit.

\section{Daftar Pustaka}

Abdullatif, M. 2013. Fraud risk factors and audit programme modifications: Evidence from Jordan. Australasian Accounting Business and Finance Journal, 7(1), 59.

Asare, S., Cohen, J., dan Trompeter, G. 2005. The effect of non-audit services on client risk, acceptance and staffing decisions. Journal of Accounting and Public Policy, 24(6): 489520. 
Bell, T. B., Landsman, W. R., dan Shackelford, D. A. 2001. Auditors' perceived business risk and audit fees: Analysis and evidence. Journal of Accounting research, 39(1), 35-43.

Boone, J. P., Khurana, I. K., dan Raman, K. K. 2010. Do the Big 4 and the Second-tier firms provide audits of similar quality?. Journal of Accounting and Public Policy, 29(4), 330352.

Chen, Yahn Shir., dan Hsu, Joseph C.S. 2009. Auditor Size, Auditor Quality, and Auditor Fee Premiums: Further Evidence from the Public Accounting Profession. National Yunlin University of Science and Technology.

Cohen, J., Krishnamoorthy, G., dan Wright, A. M. 2005. Corporate governance and the audit process. Contemporary accounting research, 19(4), 573-594.

Colbert, J. L., Luehlfing, M. S., dan Alderman, C. W. 1996. Engagement risk. The CPA Journal, 66(3), 54.

depnakertrans. 2015. Website resmi departemen ketenagakerjaan dan transmigrasi

http://ppid.depnakertrans.go.id/hadapi-mea-2015-pemerintah-fokus-siapkan-8-profesi-prioritas/

DeAngelo, L. E. 1981. Auditor size and audit quality. Journal of Accounting and Economics, 3(3): 183-199.

DeAngelo, L. E. 1981. Auditor independence,'low balling', and disclosure regulation. Journal of accounting and Economics, 3(2), 113-127.

DeFond, M. L., Raghunandan, K., dan Subramanyam, K. R. 2002. Do non-audit service fees impair auditor independence? Evidence from going concern audit opinions. Journal of accounting research, 40(4), 1247-1274.

Diaz, M. 2009. Analisis Reaksi Pasar Terhadap Pengumuman Pergantian Kantor Akuntan Publik (Studi Pada Perusahaan Publik Di Indonesia). In Seminar Nasional Akuntansi ke (Vol. 12).

Firth, M., Rui, O. M., dan Wu, X. 2012. How do various forms of auditor rotation affect audit quality? Evidence from China. The International Journal of Accounting, 47(1): 109-138.

Francis, J. R., dan Yu, M. D. 2009. Big 4 office size and audit quality. The Accounting Review, 84(5), 1521-1552.

Houston, R. W. 1999. The effects of fee pressure and client risk on audit seniors' time budget decisions. Auditing: A Journal of Practice \& Theory, 18(2): 70-86.

Houston, R. W., Peters, M. F., dan Pratt, J. H. 1999. The audit risk model, business risk and audit-planning decisions. The Accounting Review, 74(3): 281-298.

Huss, H. F., Jacobs, F. A., Patterson, D. M., dan Park, M. 2000. An integrative model of risk management in auditing. American Business Review, 18(2): 113.

Institut Akuntan Publik Indonesia. 2008. Panduan Audit Entitas Bisnis Kecil. Jakarta: Salemba Empat.

Jenkins, D. S., dan Velury, U. 2011. The emergence of second-tier auditors in the post-SOX era: An analysis of accounting conservatism. Research in Accounting Regulation, 23(2), 172-176.

Johnstone, K. M. 2000. Client-acceptance decisions: Simultaneous effects of client business risk, audit risk, auditor business risk, and risk adaptation. Auditing: A Journal of Practice \& Theory, 19(1): 1-25.

Johnstone, K. M., dan Bedard, J. C. 2003. Risk management in client acceptance decisions. The Accounting Review, 78(4): 1003-1025. 
Krishnan, J., dan Krishnan, J. 1997. Litigation risk and auditor resignations. Accounting Review, 539-560..

Li, C. 2009. Does Client Importance Affect Auditor Independence at the Office Level? Empirical Evidence from Going-Concern Opinions*. Contemporary Accounting Research, 26(1), 201-230.

Mustofa. 2014. Manajemen Modern Bisnis Kantor Akuntan. Jakarta: Buku Kompas.

pppk.2015. Website resmi Pusat Pembinaan Profesi Keuangan. Pendapatan The Big Four Masih TInggi. http://pppk.kemenkeu.go.id/News/Details/18.

Pratt, J., dan Stice, J. D. 1994. The effects of client characteristics on auditor litigation risk judgments, required audit evidence, and recommended audit fees. Accounting Review: 639-656.

Selling, T. I., dan Stickney, C. P. 1989. The effects of business environment and strategy on a firm's rate of return on assets. Financial Analysts Journal,45(1), 43-52.

Wibowo, A., dan Rossieta, H. 2009. Faktor-faktor determinasi kualitas audit-suatu studi dengan pendekatan earnings surprise benchmark. Simposium nasional Akuntansi XII, 1-34.

Wondabio, L. S. 2006. Evaluasi Manajemen Risiko Kantor Akuntan Publik (KAP) dalam Keputusan Penerimaan Klien (Client Acceptance Decisions) Berdasarkan Pertimbangan dari Risiko Klien (Client Risk), Risiko Audit (Audit Risk), dan Risiko Bisnis KAP (Auditorâ $€^{\mathrm{TM}}$ s Business Risk). Jurnal Akuntansi Keuangan Indonesia. 